\title{
木造住宅の保有水平耐力分布と ULTIMATE HORIZONTAL RESISTANT その推定法 FORCE DISTRIBUTION OF JAPANESE WOODEN HOUSES AND THEIR ESTIMATION METHOD
}

山田耕司 —

キーワード

軸組木造住宅, 雑壁, 保有水平耐力, 柔床, 壁量

Keywords :

Japanese wooden house, Non-structural wall, Ultimate horizontal resistant force, Flexible horizontal diaphragm, Wall-length ratio

\section{Koji YAMADA $-* 1$}

In this paper, the ultimate horizontal resistant force of Japanese wooden houses considering the stiffness of both floor and non-structural walls is discussed. The analytical model has the restoring force characteristic composed of the floor, bracing bearing walls and non-structural plaster board walls. The results may be summarized as follows: The increase of floor stiffness does not make the ultimate horizontal resistant force increased efficiently. The easy calculation method gives the lower limit of the ultimate horizontal resistant force.

\section{1. 序}

2 階建軸組木造住宅の耐震安全性は、一般には壁量により判断され る. 一方, 軸組木造住宅は, 不整形な平面・立面形状の建物が多く, R C 造や鉄骨造と違い㓮接合・㴊床を作成し難いことも知られてい る.また，木造住宅の耐震性能分布に関する資料は少ない，軸組木造 住宅の保有水平耐力や床剛性に関する近年の報告として，柴田らが1 8棟の戸建て住宅の資料を基に木造住宅の保有水平耐力と必要保有水 平耐力について論じている1)。 また，村上らは水平構面の剛性を考慮 した設計法を提案し，ねじれ応答に対する変位の補正方法を提起して いる2).

著者も床剛性と保有水平耐力関係に注目し既存建物をモデル化し て保有水平耐力を求め，その分布傾向を明らかにした ${ }^{3)}$ 。しかし既報 3)では，床剛性と雑壁を考慮した木造住宅の保有水平耐力を計算上の 都合から，加力直交方向壁の耐震性能と建物のねじれを無視した簡易 法で計算していた，そのため，既報で無視した事項を考慮した保有水 平耐力を求め，その分布を明らかにし，簡易法の有用性を明らかにす る必要が取り残されていた。 そこで本報では，保有水平耐力を再度計 算し，壁量充足率，既報の簡易法による保有水平耐力と比較し，簡易 な保有水平耐力推測法を検討する.

\section{2. 各種仮定・使用する既存建物の壁量}

\section{1 建物モデルの仮定}

解析モデルは, 図 1 に示すように矩形の壁要素・床要素・屋根要素

\section{から成る.}

壁要素のモデル化は，図 2 に示すように，壁を水平力抵抗要素と考 え,その壁長と単位長さ当たりの耐力特性の積で表されるせん断バネ と仮定し，壁の両端に壁耐力と等価なバネ要素を 2 分して配置した。 壁要素の復元力特性は, 耐力壁と雑壁から成る. 耐力壁量は設計図書 に示されている耐力壁種類に応じた壁倍率と耐力壁長さを乗じて計 算した。なお，今回用いた資料の耐力壁は，筋かい耐力壁のみであっ た. 雑壁量は無開口壁のみを算定対象とし，垂壁，腰壁は雑壁量に算

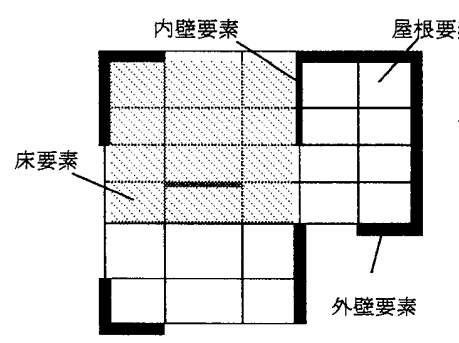

1 階

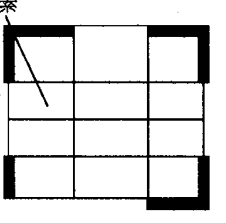

2 階

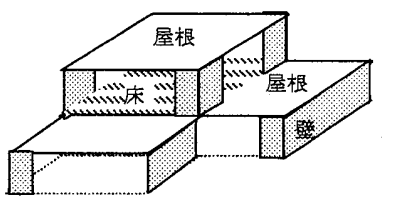

図 1 建物解析モデル例

*1 豊田工業高等専門学校建築学科 助教授 ·博士 (工学) (广471-8525 豊田市栄生町2-1)

*1 Assoc., Prof., Toyota National College of Technology, Dr. Eng. 
入しない. また, 雑壁は大壁形式, 外周壁においては片面貼り, 内壁 においては両面貼りと仮定した．また，質量は表 1 の值から計算した 質量を, 集中質量として, 壁要素の各節点に等分して配置した.

床要素と屋根要素のモデル化は, 図 3 に示すように, せん断変形・ 剛体変位・剛体回転を表現する矩形要素とした。この要素では, 要素 内節点間に設定した仮想梁要素の引張り剖性を十分に剛 $(10 \mathrm{~cm} * 30 \mathrm{~cm}$ 断面のスギ相当）としているため，せん断変形が卓越する．そこで， せん断変形角をパラメータとする復元力特性を与えている. ただし, 床および屋根は同じ復元力特性とした。 また，質量は表 1 の值から計 算した質量を, 集中質量として, 床要素・屋根要素の各節点に等分し て配置した.

本法では既報引の加力直交方向壁の耐震性能と建物のねじれを無視 した保有水平耐力計算法を簡易法と位置づける. 簡易法の建物モデル では図 4 のように加力方向に質量と水平力抵抗要素を縮約したモデ ルとする. 縮約に際しては, 耐力壁もしくは雑壁の存在する通り芯を 壁線と設定し，その壁線毎に質量・水平力抵抗要素をまとめる. 壁線 毎の水平力抵抗要素は耐力壁および雑壁の壁長と各々の耐力特性を 乗じて得られるせん断バネの和とし, 床の荷重伝達特性も床の加力方 向長さを乗じ，壁線間距離で除したせん断バネと仮定した．従って， 床の㓮体回転成分は拘束されている．また，加力直交方向の壁の剛性 は無視し，質量のみ算定している。

\section{2 壁および床・屋根の骨格曲線と復元力特性}

図 5 に文献4)に基づく壁1m当たりの骨格曲線を示す.なお，二割筋 かいの骨格曲線は，最大耐力が $6 \mathrm{kN} / \mathrm{m}$ 程度が壁倍率からして妥当であ る $(2 \mathrm{kN} / \mathrm{m} *$ 壁倍率 $2.0 * 1.5=6 \mathrm{kN})$ と判断したので, 最大耐力が $6 \mathrm{kN} に$

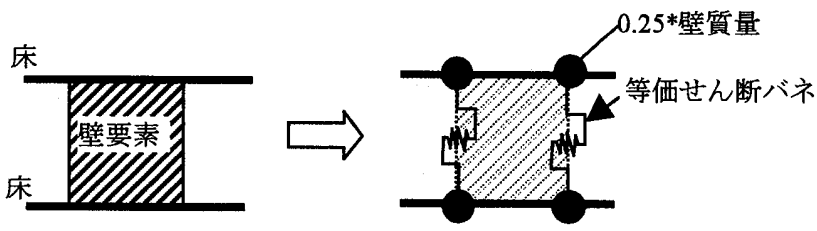

図 2 壁のモデル化

$0.25 *$ 屋根質量 or $0.25 *$ (床質量十積載物)

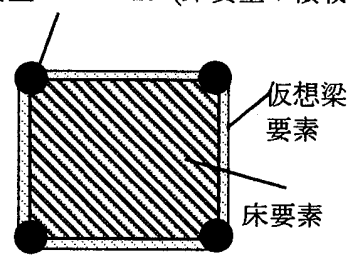

a) 床（屋根）モデルの構成<smiles>C1C2C3CC4C1C2C34</smiles>

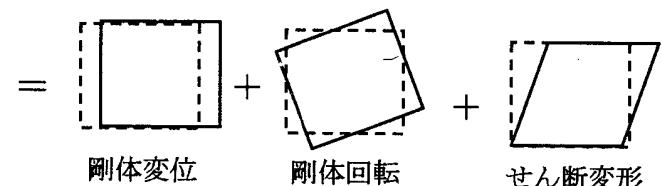

b) 床（屋根）構面の水平変位

図 3 床のモデル化
なるように剛性を低减した。また，石育ボード雑壁の最大耐力を $1 \mathrm{kN}$ /m程度と考え, 石高ボード雑壁の骨格曲線は石高ボードの骨格曲線の 0.33倍と仮定している，なお，骨格曲線は，文献4)のBi-linear + S lip 型の履歴モデルより作成している.

床および屋根の復元力特性は、文献5), 6) を参考に図 6 の “合板床” と“4 隅火打ち”とした。“合板床” は河合の文献6)を採用し，“4

表 1 建物質量の仮定

\begin{tabular}{|l|l|l|}
\hline 項目 & 質量 & 備考 \\
\hline 重い屋根 & $90 \mathrm{~kg} / \mathrm{m}^{2}$ & 施行令を参考（軒の深さは 0.75m とする) \\
\hline 軽い屋根 & $60 \mathrm{~kg} / \mathrm{m}^{2}$ & 施行令を参考（軒の深さは 0.75m とする) \\
\hline 外壁 & $190 \mathrm{~kg} / \mathrm{m}$ & サイデイング+軸組+ボード内壁 \\
\hline 内壁 & $95 \mathrm{~kg} / \mathrm{m}$ & $\begin{array}{l}\text { ボード内壁+軸組+ボード内壁 } \\
\text { (雑壁長は壁実長の2 倍になる) }\end{array}$ \\
\hline 床 & $50 \mathrm{~kg} / \mathrm{m}^{2}$ & 施行令を参考 \\
\hline 積載物 & $60 \mathrm{~kg} / \mathrm{m}^{2}$ & 施行令を参考 \\
\hline
\end{tabular}

外壁・内壁は壁 $1 \mathrm{~m}$ あたりの質量、その他は床面積 $1 \mathrm{~m}^{2}$ ありの質量

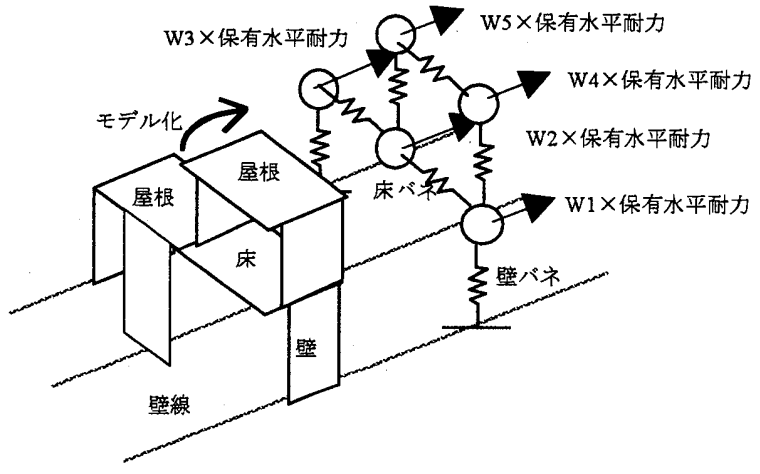

図 4 壁線に基づくモデル化

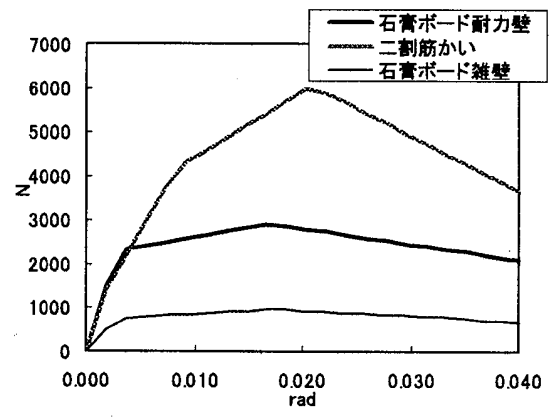

図 5 壁 $1 m$ 当たりの骨格曲線

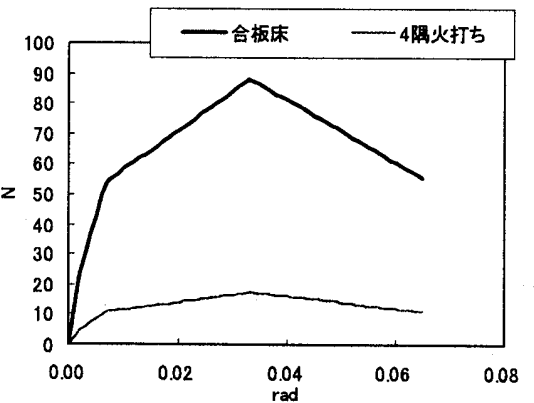

図6 床加力方向長さ $1 \mathrm{~cm}$ 当たりの骨格曲線 
隅火打ち”は文献5)骨格曲線の1/100rad時の耐力と同じになるよう に “合板床”の復元力特性を低減したものである. 計算時には図 3 の 特性に加力方向の床の長さを乗じて㓮性・耐力を算定している.

\section{3 保有水平耐力の計算法}

保有水平耐力は変位增分法で計算した場合のベースシア係数の最 大值 (以下, 保有水平耐力と称す) および， 1 階の最大層間変位が $55 \mathrm{~mm}$ (耐力壁の最大耐力時の層間変位) 時のベースシア係数（以下， $55 \mathrm{~mm}$ 時耐力と称す) を計算した，変位増分法は，ベースシア俰数にして 0.01 の初期載荷により最大変位節点を確定した後, その最大変位節 点を参照点として, $2 \mathrm{~mm}$ 単位で変位増分を行っている.

各階における水平力分布は，2 階建ての建物では 2 階が破壊する事 例が少ないこと，Ai 分布による水平力の仮定が剛床モデル以外では 難しいことより，今回の解析では各跸の質量に比例した水平荷重を各 節点に載荷している.

また，上記以外に，簡易法として，図 4 に示すモデル化を行った場 合の耐力も求めた（以下，簡易法保有水平耐力および簡易法 $55 \mathrm{~mm}$ 時 耐力と称す）．なお，簡易法で計算する場合は，各壁線が負担する質 量の範囲は各壁線間の 2 等分点を境界として設定している.

\section{4 充足率の定義}

建物内に存在する水平抵抗部材量の自重に対する比率を表す値と して以下の充足率を定義する.

充足率 $=$ 耐力壁量 $/$ 所用有効壁長

表 2 所用有効壁長 (m)

\begin{tabular}{|l|c|c|}
\hline & 1 階 & 2 階 \\
\hline 軽い屋根 & $0.11 \mathrm{~A}_{1}+0.18 \mathrm{~A}_{2}$ & $0.15 \mathrm{~A}_{2}$ \\
\hline 重い屋根 & $0.15 \mathrm{~A}_{1}+0.18 \mathrm{~A}_{2}$ & $0.21 \mathrm{~A}_{2}$ \\
\hline
\end{tabular}

$\mathrm{A}_{1}, \mathrm{~A}_{2}$ : それぞれ 1 階, 2 階の床面積 $\left(\mathrm{m}^{2}\right)$

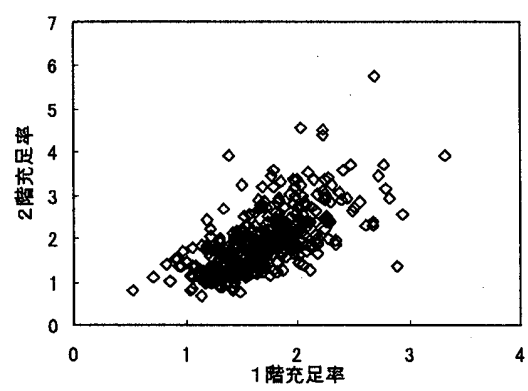

図 7 使用した建物の充足率の分布

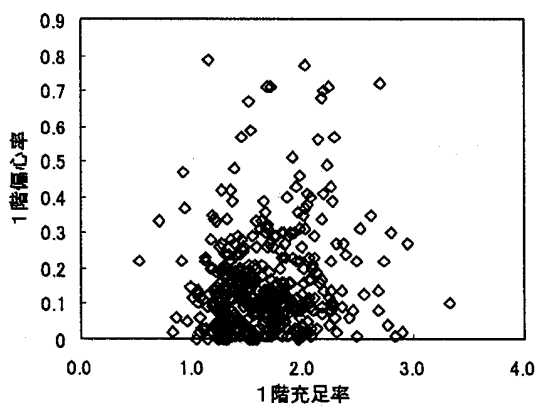

図 8 使用した建物の 1 階充足率と偏心率の関係
ここで, 耐力壁量は “耐力壁長 $\times$ 壁倍率”で計算する. 所用有効壁長 は文献 7)に基づき, 表 2 により算出した。 また, 雑壁長を考慮した 雑壁込充足率を次式で定義する.

雑壁込充足率 $=$ (耐力壁量 $+0.5 *$ 雑壁長 $) \quad /(1.5 *$ 所用有效壁長 $)$

\section{5 使用する既存建物の充足率}

本報で使用した建物群は既報 ${ }^{8)}$ で用いた平成 8 年度に愛知県内で 建設された 2 階建て在来軸組構法木造住宅の内の 208 棟である. 充足 率の分布を図 7 に，1階偏心率の分布を図 8 , 延床面積の頻度分布を 図 9 に示す. なお当該建物の床の種類は不明である. 本報では建物の 梁間・桁行を考慮せずに各方向とも計算時のサンプルとする. 従って, 計算のサンプル数は 416 となる，1 階耐力壁充足率の平均は 1.67 , 2 階耐力壁充足率の平均 $1.90 ， 1$ 階偏心率の平均は 0.16 である. ま た，図より 1 階充足率より 2 階充足率が高いこと，1階偏心率と 1 階 充足率に相関が低いことが分かる. 延床面積は $120 \mathrm{~m}^{2}$ を中心として, 大半の建物は 100〜 $160 \mathrm{~m}^{2}$ の範囲にある.

なお、本報で使用した建物データの中には，二割筋かい以外に一部 三割筋かい耐力壁が含まれているが, 耐力壁量が同量になるように二 割筋かいに換算した。

\section{3. 結果}

\section{1 保有水平耐力の分布傾向}

本節では， 1 階充足率と保有水平耐力の関係，床㓮性增加の保有水 平耐力への影響を考察する. $55 \mathrm{~mm}$ 時耐力と保有水平耐力の関係を検 討する.

図 10 に 1 階充足率と保有水平耐力の関俰, 図 11 に 1 階雑壁込充 足率と保有水平耐力の関係を示寸. 図上り，1階充足率，1階雑壁込 充足率と保有水平耐力の閒には良い相関があること，偏心率が 0.3 を越える場合には偏心率が 0.3 以下の場合と比較して保有水平耐力 が低い事例が見られること，床剛性が向上しても充足率と保有水平耐 力の線形性が際だって向上しないこと，が分かる.

1 階充足率, 1 階偏心率をパラメータとした保有水平耐力の回帰式 を表 3 に， 1 階雑壁込充足率， 1 階偏心率をパラメータとした保有水 平酎力の回帰式を表 4 に示す. 雑壁込充足率を用いた場合は, 床種類 の違いにより係数の変動が多少見受けられる．また，偏心率・雑壁を 顧慮した場合ほど, $\mathrm{R}^{2}$ 值および標準誤差は向上するが, その絶対値は 小さい.

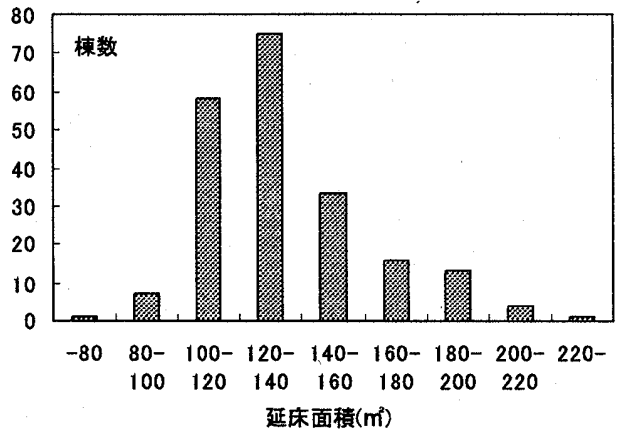

図 9 延床面積の頻度分布 
図 12 に 4 隅火打ち時の保有水平耐力と合板床時の保有水平耐力 の関係, 図 13 に床を 4 隅火打ちから合板床に変更したときの保有水 平耐力の增分を示す. 図 12 より，4隅火打ち時の保有水平耐力と合 板床時の保有水平耐力がほぼ同じであること, 図 13 よりその差が非 常に小さく, 偏心率の大小は保有水平耐力の增减にあまり関係しない ことが分かる.

以上の結果より，本報では，耐力壁, 雑壁, 床を簡単な骨格曲線で仮 定するなどの問題はあるが， 1 階充足率および 1 階雑壁込充足率によ る保有水平耐力の推定式として次式を提案する.

保有水平耐力 $=0.22+0.27 * 1$ 階充足率

保有水平耐力 $=0.08+0.35 * 1$ 階雑壁込充足率

図 14 k $55 \mathrm{~mm}$ 時耐力と保有水平耐力の関倸を示寸. 今回の耐力壁 および雑壁の復元力特性は層閒変位 $55 \mathrm{~mm}$ でほぼ最大耐力を示すため, 床の種類を問わず，保有水平耐力と $55 \mathrm{~mm}$ 時耐力は，ほぼ同じ值であ

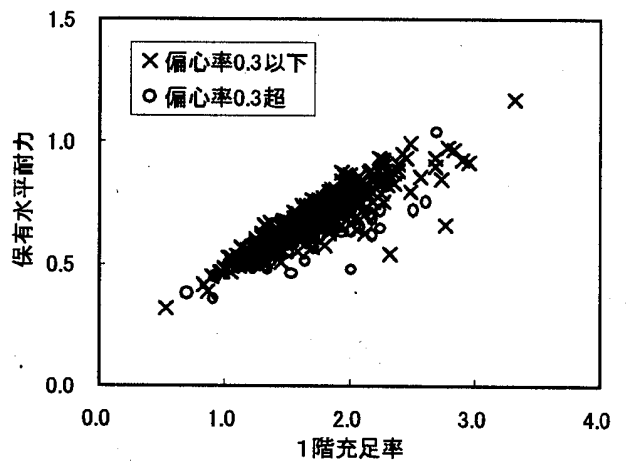

4 隅火打ち

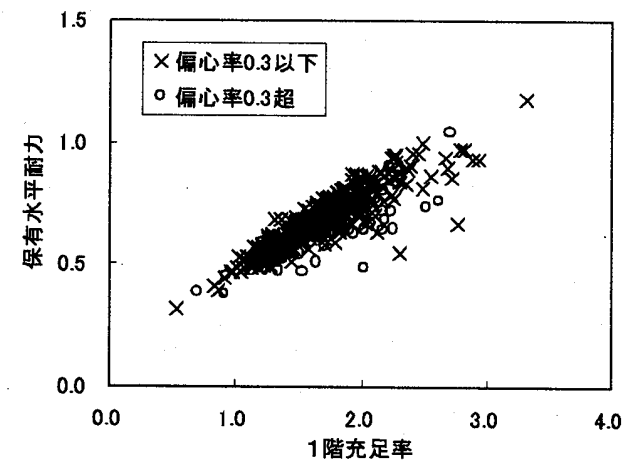

合板床

図 101 階充足率と保有水平耐力の関係

表 31 階充足率 ·偏心率と保有水平耐力の回帰式の係数

\begin{tabular}{|c|c|c|c|c|}
\hline \multirow{2}{*}{ 床の種類 } & \multicolumn{3}{|c|}{ 回帰式の係数 } & $\begin{array}{c}\mathrm{R}^{2} \text { 值 } \\
\text { (標準誤差) }\end{array}$ \\
\hline 4 隅火打ち & 0.275173 & -0.15365 & 0.226778 & $\begin{array}{c}0.805044 \\
(0.053568)\end{array}$ \\
\hline 合板床 & 0.277203 & -0.15369 & 0.229242 & $\begin{array}{c}0.806408 \\
(0.053735)\end{array}$ \\
\hline \hline 4 隅火打ち & 0.267502 & & 0.215536 & $\begin{array}{c}0.773167 \\
(0.057712)\end{array}$ \\
\hline 合板床 & 0.269369 & & 0.217800 & $\begin{array}{c}0.773819 \\
(0.058012)\end{array}$ \\
\hline
\end{tabular}

(保有水平耐力 $=\mathrm{A} * 1$ 階充足率 $+\mathrm{B} * 1$ 階偏心率 $+\mathrm{C}$ )
ることが分かる. 従って, 本報の仮定範囲内では, $55 \mathrm{~mm}$ 時耐力で保 有水平耐力を推定すればよい.

\section{2 簡易法による計算結果の有効性}

本節では，簡易解析法による保有水平耐力の推定を検討する.

簡易法保有水平耐力と保有水平耐力の関係を図 15 k, 簡易法 $55 \mathrm{~mm}$ 時耐力と保有水平耐力の関係を図 16 に示寸. 図より, 簡易法 保有水平耐力は保有水平耐力の下限を示さないが, 簡易法 $55 \mathrm{~mm}$ 時耐 力は保有水平耐力の下限を示寸ことが分かる.これは, 変位增分解析 により得られる簡易法保有水平耐力は, 図 3 中の剖体回転を無視して いるため, 水平力の再配分が発生し, 簡易法 $55 \mathrm{~mm}$ 時耐力よりも耐力 が增大したためと考えられる。 なお図 16 より，簡易法 $55 \mathrm{~mm}$ 時耐力 の精度は，床剛性が大きいほど向上することも分かる．

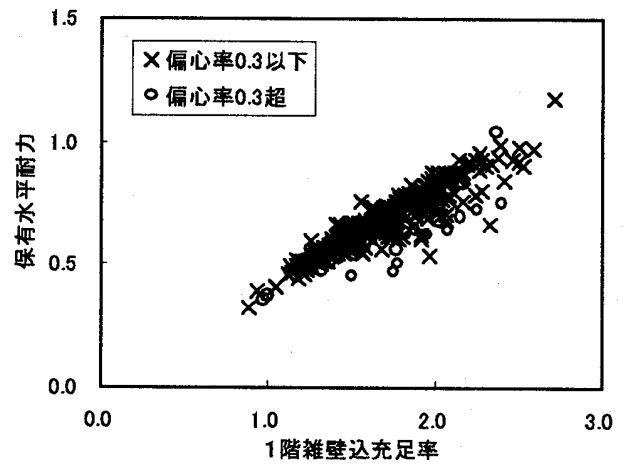

4 隅火打ち

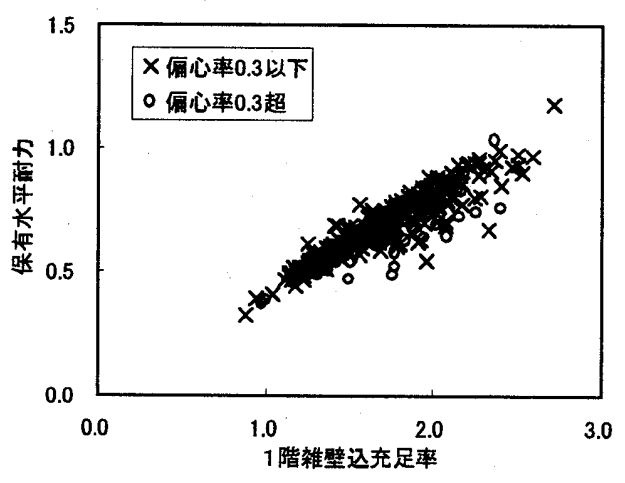

合板床

図 11 1 階雑壁込充足率と保有水平耐力の関係

表 41 階雑壁込充足率 - 偏心率之保有水平耐力の回帰式の係数

\begin{tabular}{|c|c|c|c|c|}
\hline \multirow{2}{*}{ 床の種類 } & \multicolumn{3}{|c|}{ 回㛿式の係数 } & $\begin{array}{c}\mathrm{R}^{2} \text { 值 } \\
\text { (標淮誤差) }\end{array}$ \\
\cline { 2 - 4 } 4 隅火打ち & 0.354343 & -0.12388 & 0.093329 & $\begin{array}{c}0.84738 \\
(0.047434)\end{array}$ \\
\hline 合板床 & 0.357529 & -0.12659 & 0.093395 & $\begin{array}{c}0.852695 \\
(0.046873)\end{array}$ \\
\hline 4 隅火打ち & 0.348812 & & 0.083130 & $\begin{array}{c}0.826209 \\
(0.050515)\end{array}$ \\
\hline 合板床 & 0.352177 & & 0.082972 & $\begin{array}{c}0.831129 \\
(0.050127)\end{array}$ \\
\hline
\end{tabular}

(保有水平耐力 $=\mathrm{A} * 1$ 階雑壁込充足率 $+\mathrm{B} * 1$ 階偏心率 $+\mathrm{C}$ ) 


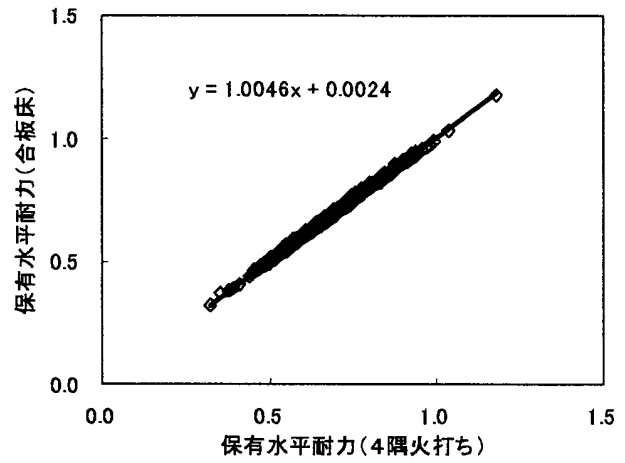

図 12 床種類による保有水平耐力の相関

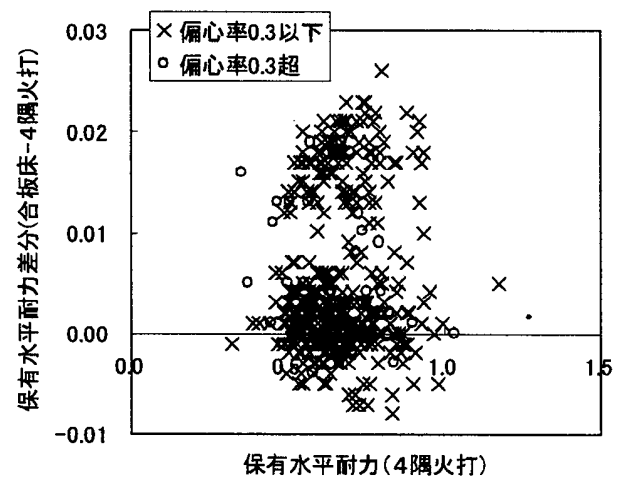

図 13 床の変更による保有水平耐力の増分

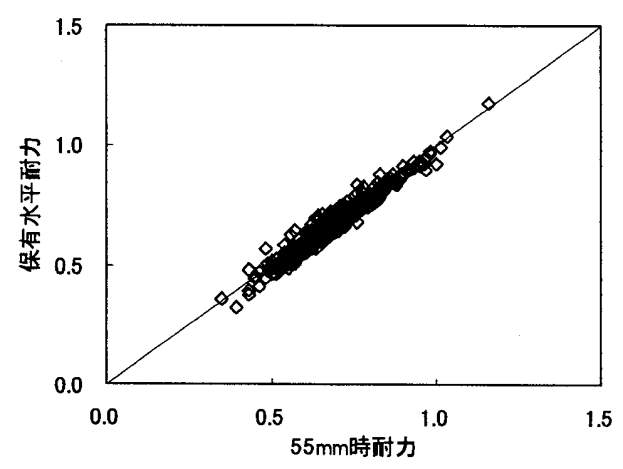

4 隅火打ち

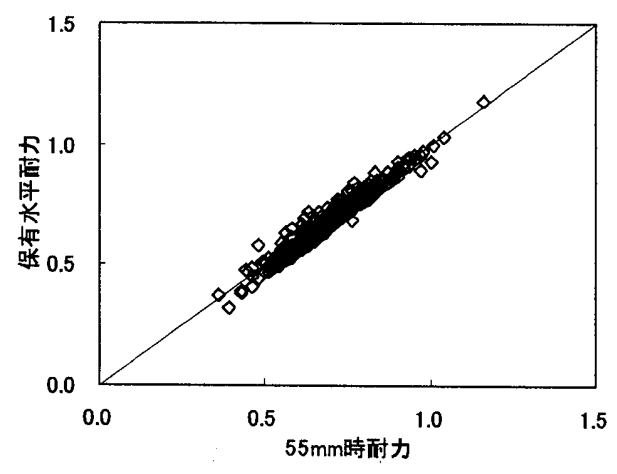

合板床

図 $1455 \mathrm{~mm}$ 時耐力と保有水平耐力の比較

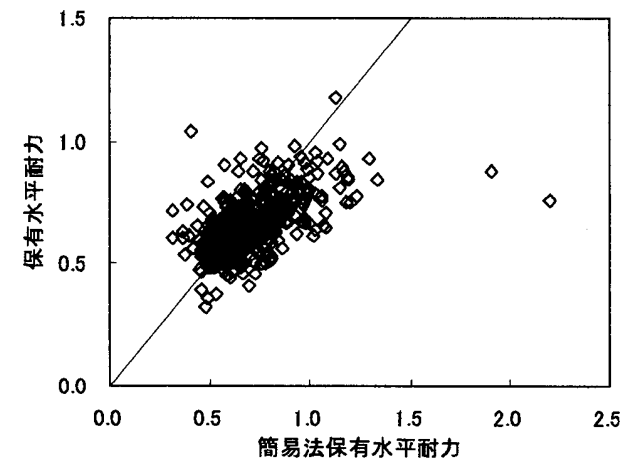

4 隅火打ち

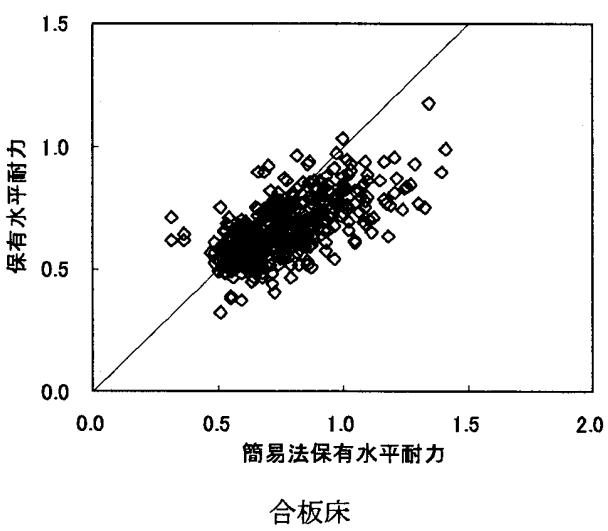

図 15 簡易法保有水平耐力と保有水平耐力の関保

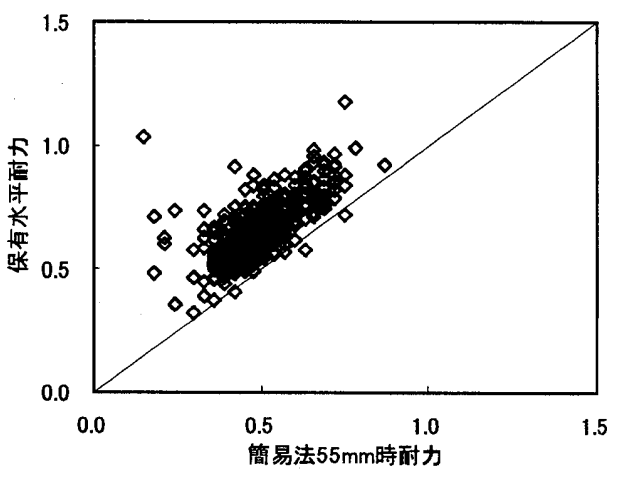

4 隅火打ち

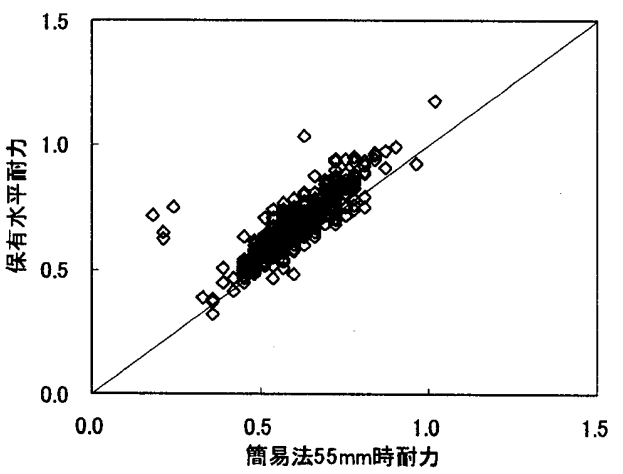

合板床

図 16 簡易法 $55 \mathrm{~mm}$ 時耐力と保有水平耐力の関係 


\section{4. 結語}

本報では, 床構面と雑壁の剛性・耐力を仮定した上で, 既存軸組木 造建物の保有水平耐力解析を行い, 保有水平耐力一の床種類の影響, 充足率や簡易解析法による保有水平耐力の推定法を考察した. その結 果, 本報では耐力壁, 雑壁, 床を簡単な骨格曲線で仮定するなどの問題 はあるが，以下の知見が得られた。

・床剛性を向上しても，建物の保有水平耐力の増分はわずかである. 従って，1つの床種類に対して保有水平耐力を計算すればよい.

・ 今回の解析仮定の下では, 建物の 1 階の最大首間変位が耐力壁の最 大耐力を生じる層間変位時の耐力を算定すれば, 建物の保有水平耐 カにほぼ等しい。

・既報で示した簡易法で保有水平耐力を計算する場合には, 簡易法に より, 建物の 1 階の最大層閒変位が耐力壁の最大耐力を生じる層間 変位時の耐力を計算すれば, 保有水平耐力の下限となる.

\section{謝辞}

本研究の一部は文部科学省科学研究補助金・基盤研究 (A) (1)「木造 建物の構造力学的解明と静的 - 動的性能評価に関する研究」（課題番 号：13305036）によって実施したものであることを付記する.

\section{参考文献}

1）武田 寛,柴田 拓二: 木造住宅の保有耐力と壁量に関する研究, 日本建筑学 会大会学術講演梗概集（近畿）, C-1, pp. 207-208, 1996

2）村上雅英, 稲山正弘 : 偏心を有する柔床壁式構造物の勒性設計法, 日本建筑 学会構造系論文集, №. 530, pp. 93-96., 2000

3）山田耕司：林用性と耐力壁線を考虑した在来軸組木造構法住宅の耐震性能 評価に関する研究，日本建策学会構造系論文集 第 525 号, pp. 79-84, 1999

4）河合直人, 岡部実, 渡边一正 : 在来軸組構法耐力壁の耐震性能 その 2 仮 動的試呀，日本建筑学会大会学術講演梗概集（九州），pp. 135-136，1998

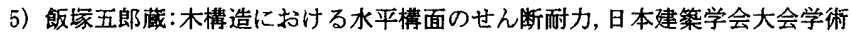
講演梗概集，C，pp. 1997-1998, 1980

6）河合直人：水平構面のせん断変形を考慮した等価線形化法の適用，日本建 築学会大会学術講演梗概集（東北），pp. 203-204，2000

7）建設省住宅局 : 木造住宅の耐震精密診断と補強方法, 1985

8）山田耕司：愛知県の在来軸組木造住宅の壁量に関する調查研究，構造工学 論文集 Vo1. 46. B, pp. 181-188.，2000

[2003年 1 月30日原稿受理 2003年 7 月29日採用決定］ 